\title{
Bouviers Des Flandres
}

National Cancer Institute

\section{Source}

National Cancer Institute. Bouviers Des Flandres. NCI Thesaurus. Code C53748.

The Bouviers Des Flandres is a powerful dog with a massive and heavily-coated head with a thick beard and mustache and shaggy eyebrows. It has a double coat, and the rough, shaggy-looking outer coat is harsh and dry to the touch. This steel-wool hair comes in black, fawn, gray, or brindle. Height: 22-28 inches (56-71 cm.) Weight: 60-90 pounds (27$41 \mathrm{~kg}$.) 